DOI: https://doi.org/10.24144/2409-6857.2018.1(51).356-362

УДК 336.711:005.591(4-11)

\author{
Павлюк О.O.
}

\title{
РОЗВИТОК СИСТЕМ БАНКІВСЬКОГО НАГЛЯДУ В КРАЇНАХ СХІДНОЇ ЄВРОПИ
}

\begin{abstract}
Метою банківського нагляду є стабільність банківської системи. Аналіз сучасної специфіки діяльності банків краӥн Східної Свропи показує, щчо вразливість фінансової системи пов'язана з функиіями банків, депозитно-кредитними операціями, розподілом ризиків та забезпеченням ліквідності. Завданням нагляду є розповсюдження надійної практики управління ризиками в банківський системі країн Центральної Свропи з урахуванням національних особливостей розвитку. Такий підхід дозволить більш ефективно реалізовувати иілі пруденційного банківського нагляду.
\end{abstract}

Ключові слова: банківський нагляд, банківське регулювання, фінансова система, банківська система, регулятор банківської системи, ризики банківської системи.

Постановка проблеми. Світова фінансова криза, яка почалася в 2007 році в країнах Свропи, окреслила проблеми банківської системи. Особливо вразливими до кризового шоку були фінансові системи в країнах 3 перехідною економікою. Криза показала, що банки, незважаючи на достатній рівень капіталу, стикалися 3 труднощами забезпечення себе достатньо ліквідними активами, а також важливість ліквідності для належного функціонування фінансових ринків i банківського сектора. Європейський банківський ландшафт глибоко змінився в результаті регуляторних відповідей на світову фінансову кризу 2007-2008 років в Єврозоні. Але зміни в економіці i регуляторному середовищі висвітлили ряд невирішених питань в проблематиці європейського банкінгу. Тому необхідним є дослідження цих ключових питань, оскільки навіть після суттєвих регуляторних реформ продовжуються дебати про подальші реформи, які необхідні для посилення регуляторної бази СС для обмеження майбутніх ризиків в банківській системі країн Центральної та Східної Європи.

Аналіз останніх досліджень і публікацій. Відповідно з Угодою про асоціацію з СС Україна взяла на себе зобов'язання впровадити європейські вимоги до капіталу та ліквідності (пакет CRR/CRD IV), які базуються на рекомендаціях Базельського комітету. Ці вимоки окреслено також в Звіті про фінансову стабільність НБУ на 18 грудня 2017 року [11]. А саме мова йде про активізацію реформи капіталу та ліквідності відповідно до взятих зобов'язань, а

(c) Павлюк Олена Олександрівна, к.е.н., доцент, докторант кафедри міжнародних фінансів ДВНЗ "Київський національний економічний університет ім. В.Гетьмана", м. Київ, тел.: 0503849389, email: elena_pavluk@ukr.net за окремими позиціями впровадження реформ буде здійснюватися з урахуванням національних особливостей, що дозволено нормами пакету CRR/CRD IV.

Директива адекватності капіталу (Capital Adequacy Directive) [5] - це європейська директива, яка спрямована на встановлення єдиних вимог до рівня капіталу як для банківських установ, так і для небанківських фірм, які здійснюють операції 3 цінними паперами. Ця директива була вперше видана в 1993 році і переглянута в 1998 році. Оновлена Директива достатності капіталу почала діяти 3 2006 року. Директива 3 регулювання достатності капіталу The Capital Requirements Directive (CRD IV) була спрямована на регулювання галузі фінансових послуг вропейського союзу, а саме впровадження системи нагляду в Свропейському союзі, яка відображає правила Базель III по вимірюванню капіталу і стандартів капіталу.

Попередні Директиви достатності капіталу (2006/48 і 2006/49) [2;3] були замінені новим законодавчим пакетом, відомим як "CRD IV". Цей пакет, який діє 31 січня 2014 року i складається з Постанови ЄС № 575/2013 [6] та Директиви 2013/36 / ЕС [4]. Це третій пакет поправок до первинних директив після двох попередніх наборів поправок, прийнятих Комісією в 2008 році (CRD II) і 2009 (CRD III). CRD IV замінила Директиву про вимоги щодо капіталу (2006/48 / EC та 2006/49 / EC) (CRD) новою директивою та нормативними актами: Директивою CRD IV (2013/36 / СC) та Положенням про вимоги щодо капіталу ( 575/2013) (Capital Requirements Regulation, CRR). Основна роль CRD IV полягає у впровадженні в ЄC ключових реформ Базеля III, узгоджених у грудні 2010 року. До них відносяться поправки до визначення капіталу та кредитного ризику контрагента та запровадження коефіцієнта ліквідності та вимог ліквідності. Глобальна мета 
цього нового набору правил полягає в зміцненні стійкості банківського сектора ЄС 3 тим, щоб зробити його краще в умовах економічних потрясінь та створити необхідні умови банкам для фінансування економічної активності i зростання. Особливо важливим $є$ аналіз цього пакету документів в контексті його імплементації в банківський нагляд країн Східної Європи та зокрема України, оскільки НБУ анонсував запровадження директив $\mathrm{CC}$ та Базельських рекомендацій в банківський нагляд. Це міститься в Комплексній програмі розвитку фінансового сектору України до 2020 року, зокрема передбачається впровадження нових вимог до капіталу банків відповідно до принципів Базель 3 та вимог ЄС (з 1.01.2015 року по 31.12.2019 року). Цим новітнім процесам i присвячується стаття.

Формулювання цілей статті. Впровадження Європейських стандартів банківського регулювання та нагляду в Україні, яке було задекларовано керівництвом НБУ, вимагає від учасників національного банківського сектора активних дій в напрямку подальшого розвитку власних методик, систем і процесів 3 підтримки достатності капіталу та управління ризиками. На відміну від європейських фінансових організацій, які ось уже понад 10 років послідовно впроваджують ці стандарти, перед учасниками українського банківського сектора стоїть непросте завдання застосування цих стандартів. Тому завданням статті $є$ порівняння суттєвих регуляторних реформ країн Східної Європи 3 метою визначення ключових тенденцій банківського нагляду та можливостей запровадження їх досвіду в банківський нагляд країн з перехідною економікою.

Опис основного матеріалу дослідження. Фінансові системи в країнах 3 перехідною економікою були особливо вразливими до кризового шоку. На думку аналітиків, в деяких країнах, таких як Угорщина та Росія, ці кризи мали ознаки системних, хоча в більшість країн 3 перехідною економікою зазнали кредитних бумів, які супроводжувалися шоком світової фінансової кризи [12,стор.625]. Досвід подолання цих наслідків показав, що ступінь стійкість до кризових потрясінь залежить від надійності вітчизняних фінансових інститутів та наявності політичних рішень для подолання цих тенденцій. Присутність іноземних банків в країнах Східної Європи, які були поширені 3 середини 1990-х років і до цього часу, з одного боку, впливали на посилення кризових явищ, а 3 іншого боку, в банківські системи країн почали приходити іноземні стратегічні інвестори, які здійснювали не тільки інвестиції в капітал банку, а і стали джерелом трансферу технологій для банків країн 3 перехідною економікою. Перша така угода була продаж Будапештського державного банку у 1995 році. Ця угода відкрила нові проекти в інших країнах, таких як Угорщина, Польща, Болгарія, Хорватія та в країнах Балтії. Винятками в Центральній та Східній Європі були Словаччина, Румунія, Сербія та Словенія. Так, наприклад, до 2005 року політика уряду Словенії обмежила іноземну участь у банківській справі. Іноземні банки принесли сучасні банківські технології та продукти. Наприклад, банківські системи були ранніми користувачами електронних пристроїв платіжних систем та імпортували кредитні скорингові моделі від своїх інвесторів. Крім того, відбувався перехід банківської справи на основу передових законів та регуляторних структур. Це часто було обумовлено тим, що до країн Східної Свропи почали надходити іноземні інвестиції в 1990-ті роки таких організацій, як USAID, Світового банку, СБРР, які надавали підтримку та досвід для написання законодавства щодо регулювання банків. Шість країн 3 перехідною економікою розпочали вступні переговори з Свропейським Союзом у 1998 році, тому їх банківські інститути почали переходити на вимоги законодавства ЄС в таких основних напрямках як: банківське право, стандартах бухгалтерського обліку та нормативних документах.

Угорщина стала першою країною Східної Свропи. яка вітала іноземну банківську власність на законодавчий основі і в 1992 році запровадила сучасне банківське право, стандарти міжнародного бухгалтерського обліку та новий закон про банкрутство. В кінці 1995 року закінчилася правова реформа, яка розпочалася в 1991 році після продажу Будапештського банку. У Чехії амбіційна програма ваучерної приватизації підприємств відбулася раніше реформи корпоративного управління та регулювання ринку капіталу. Коли Чеська Республіка вступила у переговори з ЄС, то відбулася реструктуризація i реприватизація банків. У 1999 році іноземним банкам належала чверть в чеських банківських активах та дві третини в Угорських банківських активах. До 2005 року іноземна власність становила у обох країнах близько 90\%, що сприяло проведення інституційних реформ. Вплив фінансової кризи на країни перехідного періоду був суттєвий, оскільки попит на їх експорт скоротився після кризового шоку. Крім того, 3 самого початку кризи існувало занепокоєння щодо клієнтів банків в країнах 3 перехідною економікою, оскільки більшість фінансових послуг 
надавалися іноземними банками, і дослідження свідчать про те, що фінансова криза швидко передається в країни 3 перехідною економікою через канал володіння іноземним банком. Страх перед передачею фінансової кризи в країни 3 перехідною економікою від країн Центральної Європи призвів до розробки спеціальної міжнародної політики, яка відома як Віденська ініціатива. Відповідно 3 цією політикою та по мірі посилення глобальної кризи в січні 2009 року міжнародні фінансові установи (СБРР, МВФ та Європейський інвестиційний банк), а також приватні іноземні материнські банки в регіоні домовилися про створення фінансової підтримки задля уникнення ефектів шоку. Банки вирішили зберегти свої ризики та застосовувати рекапіталізацію банків по мірі необхідності. Наприклад, МВФ виділило для підтримки стабільності банків 33 мільярди євро. Такі країни, як Угорщина, Україна, Польща та Румунія відкрили кредитування, узгоджене 3 МВФ. Ці події сприяли посткризовій ситуації та відновлення створення банківських та кредитних ресурсів у регіоні.

Таким чином, досвід проведення реформ банківського нагляду та регулювання в країнах Східної Свропи показує, що багато західних банків у країнах, що розвиваються, працюють над своїми дочірніми компаніями з управлінням ризиками 3 централізованими на рівні групи та місцевими наглядовими органами, спираючись на головні наглядові органи материнських банків, щоб стежити за змінами у профілі ризиків своїх іноземних партнерів. Хоча іноземні банки часто можуть ухилитися від заходів регулювання, в тому числі шляхом переходу від вітчизняного до транскордонного кредитування або шляхом переведення кредитів від банків до небанківських установ, таких як лізингові установи, які належать іноземним банкам.

Цікавим є досвід розвитку банківського нагляду та регулювання Польщі, яка витримала кризу краще, незважаючи на велику іноземну власність. Це пов'язано 3 тим, що польська банківська система була менш концентрованою, a також більш конкурентоспроможною 3 різноманітною іноземною власністю та невеликим кредитуванням в іноземній валюті. Натомість в Україні фінансова криза призвела до зниження кредитування та до зміни власників із Заходу на інщих власників 3 російським капіталом. Загальні активи банківського сектора в Польщі складають приблизно 1,6 млрд злотих, а в секторі працює близько 171000 чоловік. Як правило, польські банки залишалися добре капіталізованими, коефіцієнти капіталу були комфортними за вимогами Базеля III (середній коефіцієнт достатності капіталу на рівні 15,6\%). Однак слід зазначити, що за 2015 рік спостерігався один випадок банкрутства одного 3 кооперативних банків. Це був перший випадок банкрутства у польському банківському секторі 3 2001 року. В 2015 році іноземні інвестори 3 приблизно 17 країн контролювали 61,5 відсотка активів польського банківського сектора, у тому числі 28 комерційних банків та всі філії кредитних установ ЄС. Основні інвестиції надійшли 3 Італії (13\%), Німеччини (10,4\%), Іспанії (9,1\%) та Нідерландів (9\%). Після придбання Nordea Bank Polska під контролем держави Державне казначейство Польщі збільшило свою частку до 24,1\% активів польського банківського сектора. Кредитні установи інших країн-членів ЄС можуть надавати транскордонні фінансові послуги в Польщі на основі єдиного банківського паспорту або можуть працювати в Польщі через філію. Іноземні банки можуть працювати в Польщі через дочірню компанію (формально - окремий банк, ліцензований польським регулятором) або філією (засновування філії інституцією, що не $є$ членом СС, вимагає дозволу від Polish Financial Supervision Authority, PFSA). PFSA $\epsilon$ консолідованим контролером, створеним у 2006 році внаслідок злиття регулювання ринку цінних паперів, регулювання страхової, пенсійної системи та банківського нагляду. PFSA відповідає за банківський контроль, ринки капіталу, нагляд за страховими та пенсійними схемами, а також нагляд за платіжними установами та кредитними спілками. Президент PFSA, президент Національного банку Польщі, президент Банківського гарантійного фонду та Міністерства фінансів координують свої дії 3 Комітетом з фінансової стабільності. 32007 року PFSA здійснює підхід до нагляду на основі ризику. Метою регулятора $\epsilon$ розробка гармонізованої методології нагляду, яка б використовувала ризик як основний фактор визначення пріоритетів та частоти наглядових дій та точне кількісне визначення ризиків, пов'язаних 3 діяльністю різних груп капіталу на польський ринок.

У 2015 році набув чинності Закон про макропруденційний нагляд за фінансовою системою та кризовий менеджмент у фінансовій системі. Компетентним органом макропруденційного нагляду за фінансовою системою та кризовим управлінням є Комітет 3 фінансової стабільності. При виконанні своїх завдань Комітет співпрацює 3 Європейською радою 3 системного ризику. Комітет з питань фінансової стабільності несе відповідальність за, зокрема, визначення фінансових установ, що створюють 
суттєвий ризик для фінансової системи та виконання макропруденційних інструментів, що включає викладання своєї думки та надання рекомендацій щодо обмеження системного ризику. Після впровадження Директиви CRD IV, яка набрала чинності в листопаді 2015 року, польське законодавство передбачає конкретні вимоги щодо корпоративного управління для банків. Банки, які функціонують як акціонерні товариства, регулюються загальним корпоративним законодавством 3 модифікаціями, що випливають з Закону про банківську діяльність. Спостережна рада банку має складатися щонайменше 3 п'яти осіб, а правління має складатися 3 не менше трьох. Банки повинні інформувати PFSA про склад та будь-які зміни в наглядовій та управлінській раді. Голова правління банку відповідає за внутрішній аудит. Також слід вказати, який член або члени правління відповідають за нагляд за матеріальними ризиками для діяльності банку. У 2013 році PFSA почала вивчати корпоративне управління банків. Незважаючи на кодекс корпоративного управління Варшавської фондової біржі, на якому перелічені основні польські банки, у січні 2014 року PFSA випустила власні правила корпоративного управління для фінансових установ. 1 січня 2014 р. вступив в силу пакет пакету CRD IV. Регламент CRR безпосередньо застосовується у Польщі, тоді як Директива CRD IV повинна бути запроваджена в польському законодавстві, і це було зроблено в листопаді 2015 року. Після впровадження Директиви CRD IV у відповідні положення Закону про банківську діяльність щодо власних коштів банків, внутрішніх капітал та достатність капіталу були внесені поправки, але все ще необхідно скасувати резолюції, які стали застарілими внаслідок прямого застосування Регламенту CRR та імплементації Директиви IV Директиви CRD. Набрання чинності Регламентом CRR (CRR Regulation) та впровадження Директиви CRD IV призвело до суттєвих змін у структурі власних коштів банків, які раніше регулювалися виключно положеннями Закону про банківську діяльність Польщі. В даний час банки повинні зберігати власні кошти, визначені як сума капіталу 1 рівня та 2 рівня, скориговані на розмір проведеного бізнесу. Інструменти капіталу та субординовані позики можуть бути кваліфіковані як додаткові інструменти на рівні 1 або інструменти на рівні 2 після отримання згоди PFSA. Банки зобов'язані підтримувати суму власних коштів на рівні, не нижчому від найбільшого: (1) суми, що випливає 3 виконання вимог щодо власних коштів, зазначених у положеннях CRR Regulation та
(2) суми, що оцінюється банком, необхідної для покриття всіх виявлених, суттєвих ризиків діяльності банку та змін у економічному середовищі 3 урахуванням очікуваного рівня ризику (внутрішнього капіталу). Згідно зі статтею 92 Регламенту CRR банки завжди повинні задовольняти наступним вимогам щодо власних коштів: (1) коефіцієнт капіталу першого рівня капіталу в розмірі 4,5 відсотка; (2) коефіцієнт капіталу першого рівня - 6 відсотків; (3) загальна сума капіталу становить 8 відсотків. Крім того, банки зобов'язані підтримувати резерви на капітал, зокрема захисний та антициклічний буфер капіталу. Додатковий капітал у формі антициклічного буфера збирається банками в період економічного зростання та спрямований на послаблення кредитної експансії банків, що призведе до згладжування коливання циклу. Під час економічного спаду банки будуть звільнені від вимоги підтримувати антициклічний буферний капітал, i додатковий капітал, накопичений ними в період економічного зростання, зможе бути використаний. PFSA може рекомендувати банку виконувати додаткові вимоги щодо ліквідності та власних коштів, а також наказати банку утримувати виплату дивідендів до відновлення ліквідності або досягнення інших норм ризику, що допускаються в діяльності банку. Крім того, PFSA отримала повноваження встановлювати норми ліквідності та інших допустимих операційних ризиків, що є обов'язковими для банків згідно з Резолюцією № 386/2008 від 17 грудня 2008 року. Щодо обов'язкових банківських стандартів ліквідності PFSA встановила мінімальні кількісні та якісні вимоги до управління ризиком ліквідності банками. Зокрема, банки повинні були контролювати невідповідність строків погашення, прогнозувати приплив і відтік коштів, визначати вплив їхніх філій на їх ліквідність та аналізувати можливості отримання майбутнього фінансування та його витрат, а також впровадити короткострокову (нестабільні джерела фінансування покривають ліквідні активи) та довгострокову (охоплення неліквідних активів та обмежених активів ліквідності зі стабільними джерелами фінансування) ліквідність.

У 2015 році згадані вище національні правила, що стосуються вимог щодо ліквідності, були замінені коефіцієнтом покриття ліквідності, зазначеного у Регламенті CRR та делегованому Комісією 2015/61 від 10 жовтня 2014 року, що доповнюе Регламент CRR щодо вимог щодо забезпечення ліквідності кредитних установ. Відповідно, в даний час банки мають ліквідні 
активи, сума яких покриває відтік ліквідності, за винятком притоку ліквідності в умовах стресової ситуаціі, $з$ тим щоб забезпечити, щоб установи підтримували рівні буферів ліквідності, які $є$ адекватними для будь-якого можливого дисбалансу між притоками ліквідності та відплив у сильно напружених умовах протягом 30 днів. Під час стресу банки можуть використовувати свої ліквідні активи для покриття своїх чистих відпливів ліквідності. Коефіцієнт покриття ліквідності повинен запроваджуватися поступово та досягти цільового рівня 100 відсотків 31 січня 2018 року. В 2016 році вступить в дію Директива про відновлення та вирішення банківських установ (BRRD), що призвело до запровадження змін у режимі відновлення та розв'язання.

Такі зміни в регуляторному банківському середовищі було спрямовано на зменшення фінансової кризи, міжбанківське кредитування та обмеження ризику ліквідності банків. 3 цією метою, наприклад, Національний банк Польщі прийняв пакет заходів, спрямованих на полегшення його вимог до операцій на відкритому ринку. Зокрема, трансзакції репо між комерційними банками та Національним банком Польщі можуть бути укладені на більш тривалий термін (шість місяців замість трьох), а також було розширено перелік прийнятного забезпечення, щоб включати в себе борги, видані місцевими органами влади, іпотечні боргові зобов'язання і казначейські папери, деноміновані в євро. Національний банк Польщі також знизив вимоги до обов'язкових резервів для банків та погодився викупити власні облігації до їх строку погашення. Ці інструменти виявилися достатніми під час кризи, оскільки жодний банк не був змушений звернутися до Національного банку Польщі 3 проханням про надання індивідуальної допомоги з ліквідності.

Таким чином, найбільший виклик, який стоїть перед банківськими системами країн Східної Європи та польською банківською індустрією, зокрема, є дотриманням нового законодавства в контексті запровадження Директиви CRD IV, що сприятиме введенню нових правил виконавчих наказів банку, нових правил розгляду скарг клієнтів та реалізації BRRD щодо гарантій вкладів. Найбільші зміни чекають на сектор кооперативних банків, оскільки кооперативні банки почнуть діяти у формі схем інституційного захисту, створених для задоволення вимог щодо капіталу та платоспроможності, встановлених CRR Regulation.

Українська банківська система також зазнала кризи останніх років. За даними Національного банку України 31 лютого 2016 року по 1 грудня 2016 року кількість діючих банків скоротилася 3 116 до 98, також скоротилися активи банків 3 1293104 млн грн до 1263359 млн грн. В грудні 2016 року відбулася націоналізація системного банку Приватбанку. Як було повідомлено в меморандумі, націоналізація відбулася 3 метою збереження фінансової стабільності та задля забезпечення відповідності всіх українських банків нормативним вимогам НБУ. За даними НБУ загальна потреба Приватбанку в капіталі становила 148 млрд грн. Аналіз ситуації в фінансовому секторі України показує на наявність проблем, які свідчать про кризові явища в банківській системі України, зокрема в системі банківського регулювання та нагляду. Згідно з нормативною базою, банківський нагляд в системі Національного банку України має достатній рівень незалежності, але під час фінансової кризи, на мою думку, окреслилися проблемні питання щодо іï функціональної та інституційної складової. Ускладнення процесу регулювання впливає на ускладнення проведення банківського бізнесу, особливо в умовах девальвації гривні та тотального банкрутства банків. Відповідно 3 опублікованим оглядом банківського сектору НБУ[10], від початку 2018 року НБУ активно запроваджує директиви ЄС та Базельські рекомендації. Протягом року почне діяти новий норматив ліквідності LCR. Будуть підготовлені нові правила розрахунку регулятивного капіталу, зокрема прийнятності його складових. Також НБУ започатковує щорічну оцінку стійкості фінустанов, що складатиметься 3 аналізу якості активів (для всіх банків) та стрес-тестування (для 25 банків, на які припадає 95\% активів сектору). Ключовими викликами для банківського сектору лишається висока частка непрацюючих кредитів, переважно у державних банках. Банкам слід значно активніше працювати 3 такими кредитами та визначитися 3 планами скорочення їхнього обсягу протягом року.

Висновки i перспективи подальших досліджень. Досвід проведення реформ банківського нагляду в країнах Східної Європи свідчить, що ці реформи мали на меті застрахуватися від проблемних банків та мінімізувати вплив банківських криз на клієнтів банків. Крім того, криза 2007 року торкнулася фінансових систем та реальних економік та призвела, серед іншого, до великої кількості неповернених кредитів у балансах європейських банків. Ці кризи були схожі з кризами в країнах Центральної Свропи, однак мали свої специфічні прояви такі як обмеження міжбанківського кредитування та нестача ліквідності. 
Досвід подолання кризових явищ в країнах Східної Європи показує, що тільки за умов комбінації макропруденційних заходів та запровадження Європейських регуляторних ініціатив $\epsilon$ можливим їх подолання. Про це свідчить досвід Польщі, яка запровадила Закон про макропруденційний нагляд за фінансовою системою та кризовий менеджмент у фінансовій системі. Компетентним органом макропруденційного нагляду за фінансовою системою та кризовим управлінням $є$ Комітет 3 фінансової стабільності, який при виконанні своїх завдань співпрацює з Європейською радою з системного ризику.

Банківська система України потребує від національного регулятора забезпечення прозорості в проведенні бізнесу, шляхом видання інструкції, рекомендацій, які $б$ регулювали ризик- менеджмент та запобігали банкрутству банків. Таким положенням, наприклад, могло б стати положення про підсилення регуляторних вимог до управління ризиками в банках задля наближення до найкращих світових стандартів ризик-менеджмента. Основними складовими таких вимог є: запровадження систем управління ризиками та звітності, введення внутрішньобанківських документів по управлінню ризиками, запровадження інформаційних систем по управлінню ризиками та звітності, запровадження моделей та інструментів оцінки ризиків, проведення стрестестування. Це можливо тільки завдяки зміни Закону “ Про банки та банківську діяльність”. Дослідженню перспектив запровадження сучасного досвіду в банківський нагляд України буде присвячено наступне дослідження.

\section{ПЕРЕЛІК ВИКОРИСТАНИХ ДЖЕРЕЛ}

1. Третя базельська угода (Third Basel Accord). [Електронний ресурс].- Режим доступу: http://www. bis.org.

2. Directives 2006/48/EC of the European Parliament and of the Council of 14 June 2006 on the capital adequacy investment firms and credit institutions. [Електронний ресурс]/The European Parliament and the Council. -2006.Режим доступу ресурсу:ec.europa.eu/finance/bank/regcapital/index_en.htm.

3. Directives 2006/49/EC of the European Parliament and the Council. The capital adeqvacy of investment firms and credit institutions [Електронний ресурс] / The European Parliament and the Council. - 2006. - Режим доступу до pecypcy: www:eur-lex.europa.eu.

4. Directive 2013/36/EU on access to the activity of credit institutions and the prudential supervision of credit institutions and investment firms (CRD IV) [Електронний ресурс]/The European Parliament and the Council. -2006.Режим доступу ресурсу:ec.europa.eu/finance/bank/regcapital/legislation-in-force/index_en.htm.

5. Directive 93/6/EEC of 15 March 1993 on the capital adequacy of investments firms and credit institutions.[Електронний ресурс]/The European Parliament and the Council. - 2006. - Режим доступу до pecypcy:ec.europa.eu/finance/bank/regcapital/legislation-in-force/index_en.htm.

6. Regulation (EU) №575/2013 on prudential requirements for credit institutions and investment firms (CRR). [Електронний pecypc]/The European Parliament and the Council. - $2006 . \quad$ Режим доступу pecypcy:ec.europa.eu/finance/bank/regcapital/legislation-in-force/index_en.htm/

7. Directive 2014/59/EU of the European Parliament and of the Council establishing a framework for the recovery and resolution of credit institutions and investment firms [Electronic Resource]/The European Parliament and the Council. -2016.- Режим доступу pecyрсу:ec.europa.eu/finance/bank/regcapital/legislation-in-force/index_en.htm.

8. Постанова Правління НБУ №312 від 12.05.2015 "Про затвердження Змін до Інструкції про порядок регулювання діяльності банків в Україні"[Електронний ресурс]. - 2015 - Режим доступу до ресурсу: http://zakon3.rada.gov.ua/laws/show/z1590-12.

9. Про затвердження Інструкції про порядок регулювання діяльності банків в Україні № 368 [Електронний pecypc] // НБУ. - 2001. - Режим доступу до ресурсу: http://zakon5.rada.gov.ua/laws/show/z0841-01.

10. Огляд банківського сектору [Електронний ресурс] // НБУ. - 2018. - Режим доступу до ресурсу: https://bank.gov.ua/doccatalog/document?id=64628171.

11. Звіт про фінансову стабільність [Електронний ресурс] // НБУ. - 2017. - Режим доступу до ресурсу: https://bank.gov.ua/doccatalog/document?id=60778933.

12. Wachtel P. Credit Institutions, Ownership and Bank Lending in Transition Economies / P. Wachtel, R. Haselmann, J. Sobott // The Palgrave Handbook of European Banking / P. Wachtel, R. Haselmann, J. Sobott. London: PalgraveSpringer Nature, 2016. - (Palgrave). - C. 625-626.

\section{REFERENCES}

1. Tretia bazelska uhoda [Third Basel Accord]. (n.d.).bis.org.Retrieved from: http://www. bis.org.

2. Directives 2006/48/EC of the European Parliament and of the Council of 14 June 2006 on the capital adequacy investment firms and credit institutions.(2006). ec.europa.eu. Retrieved from ec.europa.eu/finance/bank/regcapital/index_en.htm.

3. Directives 2006/49/EC of the European Parliament and the Council. The capital adeqvacy of investment firms and credit institutions.(2006). ec.europa.eu Retrieved from: www:eur-lex.europa.eu. 
4. Directive 2013/36/EU on access to the activity of credit institutions and the prudential supervision of credit institutions and investment firms (CRD IV).(2006). ec.europa.eu - Retrieved from: ec.europa.eu/finance/bank/regcapital/legislation-in-force/index_en.htm.

5. Directive 93/6/EEC of 15 March 1993 on the capital adequacy of investments firms and credit institutions.(2006).ec.europa.eu. Retrieved from:ec.europa.eu/finance/bank/regcapital/legislation-in-force/index_en.htm.

6. Regulation (EU) $\# 575 / 2013$ on prudential requirements for credit institutions andinvestmentfirms (CRR).(2013).ec.europa.eu. Retrievedfrom: ec.europa.eu/finance/bank/regcapital/legislation-in-force/index_en.htm/

7. Directive 2014/59/EU of the European Parliament and of the Council establishing a framework for the recovery and resolution of credit institutions and investmentfirms.(2016).ec.europa.eu. Retrieved from: ec.europa.eu/finance/bank/regcapital/legislation-in-force/index_en.htm.

8. Pro zatverdzhennia Zmin do Instruktsii pro poriadok rehuliuvannia diialnosti bankiv v Ukraini [On Approval of Changes to the Instruction on the Procedure for Regulating the Activities of Banks in Ukraine].(2015). rada.gov.ua. Retrieved from: http://zakon3.rada.gov.ua/laws/show/z1590-12. [in Ukrainian]

9. Pro zatverdzhennia Instruktsii pro poriadok rehuliuvannia diialnosti bankiv v Ukraini \# 368 [On Approval of the Instruction on the Procedure for Regulating the Activities of Banks in Ukraine No. 368]. (2001). rada.gov.ua. Retrieved from: http://zakon5.rada.gov.ua/laws/show/z0841-01. [in Ukrainian]

10. Ohliad bankivskoho sektoru [Overview of the banking sector].(2018). bank.gov.ua.Retrieved from: https://bank.gov.ua/doccatalog/document?id=64628171. [in Ukrainian]

11.Zvit pro finansovu stabilnist [Financial Stability Report]. (2017).bank.gov.ua. Retrieved from: https://bank.gov.ua/doccatalog/document?id=60778933. [in Ukrainian]

12. P. Wachtel, R. Haselmann, J. Sobott (2016). Credit Institutions, Ownership and Bank Lending in Transition Economies.- London: PalgraveSpringer Nature.[in English]

Одержано 14.03. 2018 p. 